Original Article

\title{
Benthic community ecology for Algerian river Seybouse
}

\author{
Ecologia da comunidade bêntica para o rio Seybouse da Argélia
}

\author{
A. Baaloudja* (D, P. R. De los Ríos-Escalante ${ }^{b, c}$ (D) and C. Esse ${ }^{d}$ (i) \\ aUniversity of 8 May 1945 Guelma, Faculty SNV-STU, Laboratoire de Biologie, Eau et Environnement, Guelma, Algeria \\ bUniversidad Católica de Temuco, Facultad de Recursos Naturales, Departamento de Ciencias Biológicas y Químicas, Temuco, Chile \\ 'Universidad Católica de Temuco, Núcleo de Estudios Ambientales, Temuco, Chile \\ dUniversidad Autónoma de Chile, Facultad de Arquitectura, Construcción y Medio Ambiente, Unidad de Cambio Climático y Medio Ambiente \\ (UCCMA), Instituto Iberoamericano de Desarrollo Sostenible (IIDS), Temuco, Chile
}

\begin{abstract}
The Seybouse is the second largest river basin in Algeria, hosting an important biodiversity and providing various ecosystem services. This watershed is highly influenced by agricultural and industrial activities, which threaten its biodiversity and ecosystem integrity. The use of benthic macroinvertebrates as biological indicators has a long tradition in developed countries and integrated into all assessments of the ecological quality of river systems. However, the macroinvertebrates of many North African regions are still not well studied, including those of the Seybouse river. The aim of this study is to assess the inventory and ecological role of benthic macroinvertebrates in inland waters of the Seybouse River and determine the impact of pollution on their spatial distributions. We sampled the benthic macrofauna of Wadi Seybouse and its affluents using regular surveys in three sites, of which one was in the upper Seybouse Bouhamdane in Medjez Amar and two in the middle Seybouse. Between December 2019 and May 2020, 10 physico-chemical parameters (pH, EC, OD, water speed, NO3, Salinity, NO2, MES, turbidity, depth) were measured in order to establish a health state diagnosis of these aquatic ecosystems. The complementary biological approach by the analysis of populations of macroinvertebrates identified 7482 individuals and 40 taxa divided into five classes: Crustaceans which were the most dominant, insects with the main orders (Ephemeroptera, Diptera, Trichoptera, Heteroptera and Odonata), Molluscs, Nematodes and Annelids. The physico-chemical analyzes and the application of the organic pollution indices indicated a strong to excessive pollution for all sites, especially in Seybouse upstream
\end{abstract}

Keywords: benthic macro-invertebrates, bio-indicators, pollution, quality, Seybouse.

\begin{abstract}
Resumo
O Seybouse é um rio no nordeste da Argélia, é o segundo maior rio, tem uma área de captação de cerca de 6.500 $\mathrm{km}^{2}$ que acolhe cerca de 1,5 milhões de habitantes. Importantes atividades agrícolas e industriais são desenvolvidas nesta bacia hidrográfica. $\mathrm{O}$ uso de macroinvertebrados bentônicos como indicadores biológicos tem uma longa tradição em países desenvolvidos e está integrado em todas as avaliações da qualidade ecológica dos sistemas fluviais. O objetivo deste estudo foi revisar o inventário e o papel ecológico dos macroinvertebrados bentônicos nas águas interiores do rio Seybouse e determinar o impacto da poluição em suas distribuições. Resultados semelhantes foram relatados para outros países e rios argelinos. Este estudo enfoca a macrofauna bentônica de Wadi Seybouse e seus afluentes. Foram prospectados 03 locais, um no alto Seybousse Bouhamdane em Medjez Amar e dois no meio Seybousse Salah Salah Salah e Oued Zimba. Entre dezembro de 2019 e maio de 2020, dez parâmetros físico-químicos ( $\mathrm{pH}, \mathrm{CE}, \mathrm{DO}$, velocidade da água, NO3, Salinidade, NO2, MES, turbidez, deth) foram medidos para estabelecer um diagnóstico do estado de saúde desses ecossistemas aquáticos. A abordagem biológica complementar pela análise de populações de macroinvertebrados identificou 7.482 indivíduos e 40 táxons divididos em cinco classes: Crustáceos que são os mais dominantes, Insetos com as ordens principais (Ephemeroptera, Diptera, Trichoptera, Heteroptera e Odonata), Moluscos, Nematóides e Anelídeos. As análises físico-químicas e a aplicação dos índices de poluição orgânica, indicaram uma poluição forte a excessiva para todos os locais especialmente Salah Salah Salah.
\end{abstract}

Palavras-chave: macroinvertebrados bentônicos, bioindicadores, poluição, qualidade, Seybouse.

\section{Introduction}

Among aquatic biological communities, benthic macroinvertebrate communities are commonly used to assess the overall health of aquatic ecosystems (Hellawell,
1986; Barbour et al., 1996). They are considerably diverse and easy to survey in the field. They include insects, molluscs, crustaceans and worms and typically inhabit

*e-mail: bafef@yahoo.fr; baaloudj.affef@univ-guelma.dz; prios@uct.cl

Received: April 26, 2021 - Accepted: August 26, 2021 
the bottoms of rivers and lakes (Barbour et al., 1999). These organisms are sensitive to environmental conditions and are generally used as indicators of environmental disturbance (Warwick and Clarke, 1993). They are recognized as a community of organisms with a specific composition, diversity and natural functional organization of a known region, and to be good indicators of the health of aquatic ecosystems due to their sedentary lifestyle and rapid response to environmental perturbations (Karr and Dudley, 1981; Norris and Hawkins, 2000; Butcher et al., 2003). They are abundant in most rivers, and hence their sampling does not impact the population dynamics of natural communities (Barbour et al., 1999).

Ecological research on running water in Algeria is developing rapidly in this country by Ait Mouloud (1987); Arab and Zebdi (1983); Djeridane and Salhi (1983); Gagneur and Aliane (1991); Gagneur (1987); Lounaci (1987, 2005); Lounaci et al. (2000); Lounaci and Vinçon (2005); Moubayed-Breil et al. (2007). In eastern Algeria, industrial activities are expanding and their waste is discharged directly into natural rivers which has an influence on aquatic fauna (Belhanachi, 2003). The anthropic influence on one of the large wadis of eastern Algeria, the Seybouse node is manifested by various activities linked to the agglomerations installed all along this watercourse (three wilayas Guelma, El-Tarf and Annaba), and to agricultural activities which are practiced throughout the watershed or directly in small plots at the edges of this ecosystem
(Djabri et al., 2012), Human influences on aquatic biocenoses are very diverse. Habitat degradation and fragmentation can cause serious problems for aquatic populations (Sellam et al., 2017). In northeastern Algeria, studies on macroinvertebrates have peaked over the past decade (Zouggaghe, 2003; Zouggaghe and Moali, 2009; Lounaci et al., 2000, Khelifa et al., 2016, Khelifa, 2019, Sellam et al., 2017; Baaloudj et al., 2020, Meziane et al., 2020, Zouggaghe, 2020), revealing significant biodiversity and endemism and highlighting different anthropogenic threats to the persistence of lotic fauna (Khelifa et al., $2021 \mathrm{a}, \mathrm{b})$.

The aim of the present study is to make an inventory of macroinvertebrates in the Seybouse river region and determine their spatial distribution across three sites. We also do a study of associations between invertebrate benthic communities and associations with physicochemical parameters in the Seybouse river. This study helps us to better understand the local macroinvertebrate diversity as well as the structure of the lotic communities.

\section{Material and Methods}

Study area: Oued Seybouse is located in the northeastern region of Algeria, is one of the largest hydrographic basins in the country, covering a total area of approximately

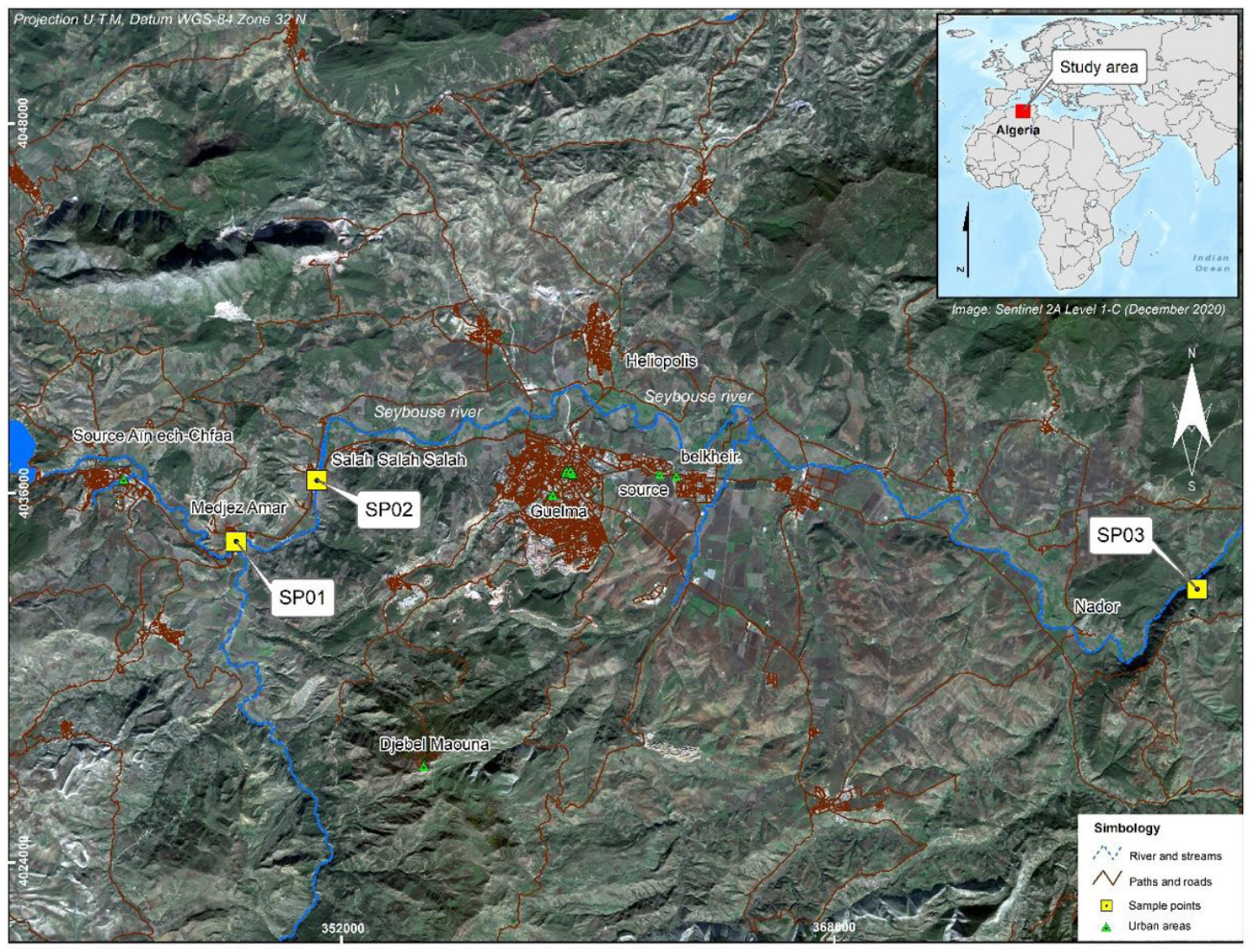

Figure 1. Map with sites included in the present study. 
6,471 km2 (Figure 1). It is characterized by three parts: the high plains (high Seybouse), the southern tell (middle Seybouse) and the northern tell (low Seybouse) (Reggam et al., 2015).

It is the second largest basin, after that of the Medjerda in the eastern part of North Africa, and it is subdivided into six main sub-basins (Blayac, 1912). It is strongly anthropogenized, bordered by human population of one million three hundred thousand $(1,300,000)$ inhabitants, divided into sixty-eight (68) municipalities and seven (07) wilayas. Thirty (30) municipalities are fully included in the basin and thirty eight (38) partially (Algeria, 1999). It crosses three wilayas (Guelma, El-Tarf and Annaba) and continuously receives discharges and wastewater from these municipalities and agglomerations. The basin's hydrographic network has a pluvial-type hydrological regime, strongly dominated by rainfall throughout the year (Reggam et al., 2015). Guelma and El-Tarf are two wilayas with an agricultural vocation with a weak industrialization (flour mills industrial production of milk and canning of tomato concentrates) and Annaba, capital of the steel, which represents industrial pole of the Algerian East: Mittal - Steel specializing in the steel industry, Fertial: chemical industry specializing in the production of insecticides and phytosanitary products (Djabri et al., 2012).

Seybouse is a river in northeastern Algeria which begins near the town of Guelma by two tributaries, Cheref and Zenati Rivers. It is bordered in north by the Mediterranean near Annaba (Figure 1). The basin of Seybouse covers a total surface of approximately $6471 \mathrm{~km} 2$ and it consists 42 rivers including Zenati, Bou Hamdane and Cherif rivers (Baaloudj et al., 2020). The two last rivers' confluence at Medjaz Amar form the Seybouse Rriver which reaches the sea of Annaba (Algeria, 1999). The study was carried out at three sites that were chosen according to their location and therefore their degree of pollution (Table 1). The vegetation mainly includes Juncus sp, Typha sp, Phragmites australis, Tamarix sp, Nerium oleander, and Lemna minor (Baaloudj et al., 2020)

Sampling: On each site, the physicochemical parameters: (water speed, conductivity, $\mathrm{O}_{2}$, $\mathrm{pH}$, salinity) were measured in situ between 8 and 12 a.m. using a multi-parameter (Multi 197i WTW), before sampling the macroinvertebrates to avoid any disturbance of the environment that could bias the results. The depth was measured at the center of the bed at the sampling location with a grid stick. And the chemical parameters $\left(\mathrm{NO}_{3}\right.$, Salinity, $\mathrm{NO}_{2}, \mathrm{MES}$, turbidity) were carried out in the ADE laboratory of H Debagh

From upstream to downstream, three sites were chosen for the study, depending on the permanence of water, accessibility in all seasons during 20182019. We sampled every month in triplicate. We have standardized the sampling effort by limiting the time spent (3h00) in each site and the number of water sweeps. The macroinvertebrates were collected from the schools using $100 \mu \mathrm{m}$ mesh diving nets by performing ten scans according to the protocol of the IBGN standard (Archaimbault and Dumont, 2010). The same method was repeated at each site. The collected sample was poured onto a $500 \mu \mathrm{m}$ mesh sieve for pre-sorting by separating various materials and collecting the samples using an entomological forceps (AFNOR, 2010). The collected organisms were fixed in formaldehyde $(10 \%)$ in labeled jars (by date and site name), and were transported to the laboratory for final analyzes. In the laboratory, samples stored in jars labeled by site were rinsed thoroughly on a series of sieves of decreasing size ( 5 to $0.2 \mu \mathrm{m}$ ) in order to remove as much as possible, the remaining fine substrate and coarse elements. The contents of the sieve were then poured onto a tray for the grouping of taxa carried out using an entomological forceps. Observation and identification were carried out using a binocular magnifying microscope using different identification keys (Leraut 2007; Tachet et al., 2010).

Data analysis: As a first step, a species presence/absence matrix was constructed, with the species in rows and the pools in columns. From this matrix we calculated a Checkerboard score ("C-score"), which is a quantitative index of occurrence that measures the extent to which species co-occur less frequently than expected by chance (Gotelli, 2000). A community is structured by competition when the C-score is significantly larger than expected by chance (Gotelli, 2000; Tondoh, 2006; Tiho and Josens, 2007). Lastly, we compared the co-occurrence patterns with null expectations via simulation. Gotelli and Ellison (2013) suggest using the statistical null model Fixed-Fixed, as in this model, when the row and column sums of the matrix are preserved. Thus, each random community contains the same number of species as the original community (fixed column), and each species occurs with the same frequency as in the original community (fixed row). The null model analyses were likewise performed using the R software ( $R$ Development Core Team, 2009) and the EcosimR package (Gotelli and Ellison, 2013; Carvajal-Quintero et al., 2015).

As a third step, a redundancy analysis was applied to the study variables - conductivity, total dissolved solids, chlorophyll concentration, water temperature, and species abundance of zooplankton - in order to determine the importance of these variables for classifying the study pools. This analysis was performed using the R software (R Development Core Team, 2009). A matrix correlation analysis was carried out to determine the associations between the study variables, using parametric Pearson correlation coefficient, after verification of normality and

Table 1. Geographical location, latitude and classification of sampling sites on the Seybousse river.

\begin{tabular}{cccc}
\hline Name & Site & Latitude $(\mathbf{S})$ / Longitude $(\mathbf{W})$ & Altitude $(\mathbf{m}$ a.s. $\mathbf{l})$ \\
\hline Medjez Amar & Site 2 & $36^{\circ} 26592 \mathrm{~N}, 007^{\circ} 18635 \mathrm{E}$. & 281,9 \\
Salh Salh Salh & Site 1 & $36^{\circ} 27.687^{\prime} \mathrm{N}, \mathrm{E} 007^{\circ} 20.363^{\prime} \mathrm{E}$ & 248,7 \\
Oued Zimba & Site 3 & $36^{\circ} 26020 \mathrm{~N}, 007^{\circ} 28471 \mathrm{E}$ & 310.5 \\
\hline
\end{tabular}


homoscedasticity conditions. The software packages used were Hmisc R (Harrell, 2016), and Vegan (Oksanen et al., 2019).

The community parameters were determined from the density analysis corresponding to the abundance of each species per sampling site, using the Shannon diversity index. Finally, the Shannon diversity indices for each site were compared based on the descriptions of Zar (1999).

\section{Results}

The abiotic parameters revealed the relative low conductivity, salinity and oxygen concentration for all studied sites, and moderate nitrate and nitrite concentrations (Table 2). The results of Shannon index for each site revealed that the low value was observed for S2 February, whereas the high value was reported for site S1- May (Table 3). The results of Shannon index comparison revealed similarities between S1-Dec with S1-Jan, S1-Jan with S3-Jan, S1-Feb with S3-Jan; S2-Dec with S3-Mar; S2-Dec with S3-Feb; S2-Dec with S2-Feb; S2-Dec with S2-Mar; S2-Dec with S2-Apr, S2-Jan with S2-Apr; S2-May with S3-Dec; S3-Dec with S3-Feb and S3-Mar with S3-May (Table 4).

The results of null model analysis revealed that species associations are random for each site and for each month, this mean that species associations are not structured (Table 5). The RDA results revealed that environmental variables, the most important contributor for axis 1 was salinity, whereas MES and nitrite were the most important contributors for axis 2 . For biotic parameters, Gammaridae and nematodes were the most important contributors for axis 1 , and for Chironomidae were the most important contributor variable for axis 2 (Table 6).

The RDA finally revealed that sites S5, has high conductivity, Nitrate and $\mathrm{pH}$ values and high Gammaridae values, and sites S4 and S6 with moderate values of this last parameters, the S14 and S15 has high values of oxygen and conductivity, sites S2 and S3 has high values of velocity and depth, and the remaining sites have high depth, Nitrite and MES values (Figure 2). In this scenario, the site S4, S5 and S6 would have high contamination and with species representatives (Gammaridae) of low oxygen concentration and high nutrients concentration, whereas sites S14 and S15 would have moderate oxygen concentrations, and nutrients concentration, and finally the sites S2 and S3, would have high water quality expressed in high oxygen concentration (Figure 2). The results RDA revealed in general no differences in benthic communities in studied sites (Figure 2).

\section{Discussion}

The exposed study about benthic fauna in the studied river, would have similarities with Mediterranean rivers such as rivers in Spain, Pacific coast of United States of America and central Chile (Figueroa et al., 2013). Although the present study did not include species determination until genus and/or species level, the existence between groups reported and its associations with environmental parameters are supported, and would be similar with results obtained by Ríos-Escalante et al. (2020) and Solis-Lufi et al.

Triplot of RDA - Scaling 3

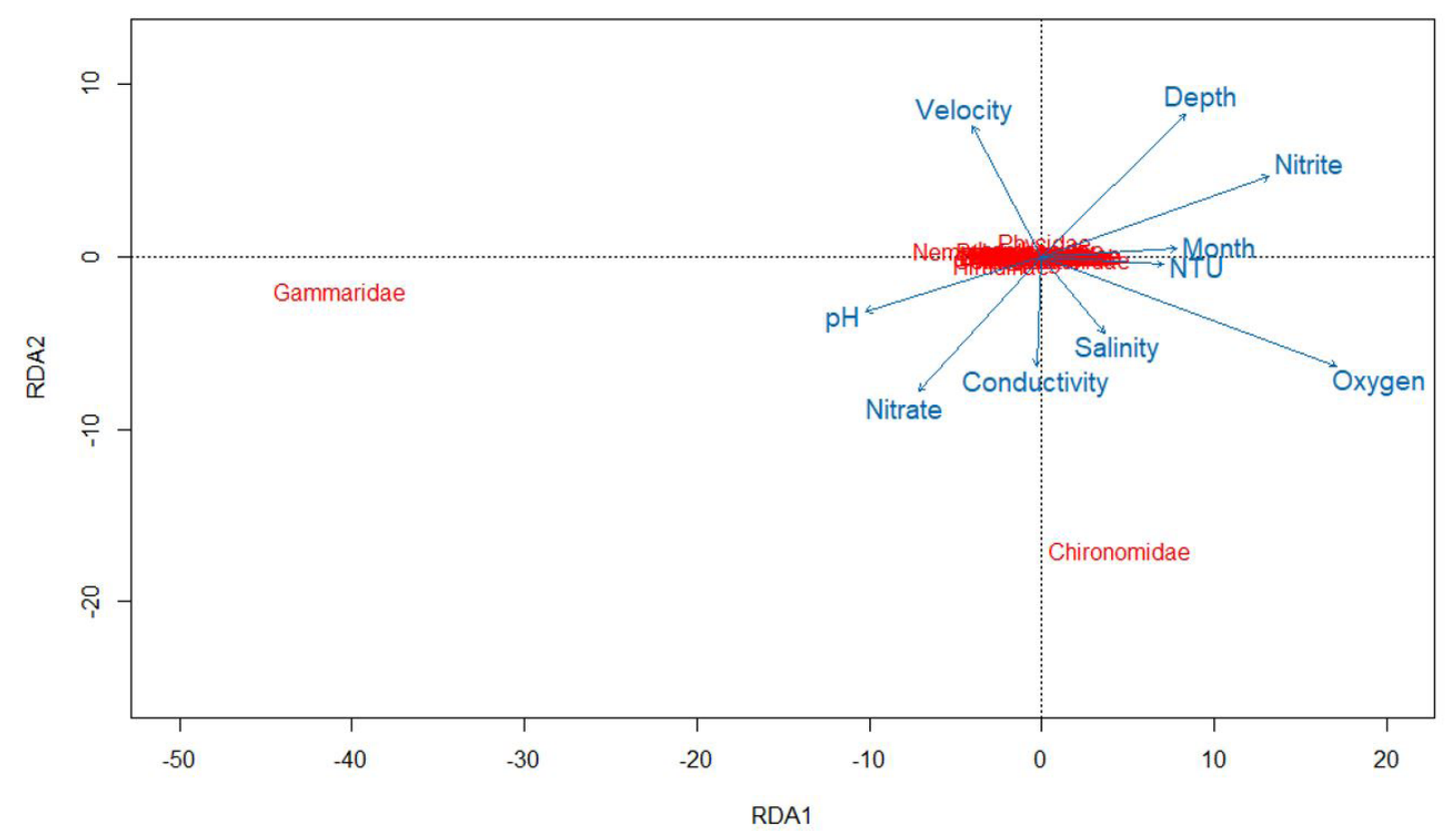

Figure 2. Results of RDA analysis for abiotic and biotic parameters for studied sites in the present study. 


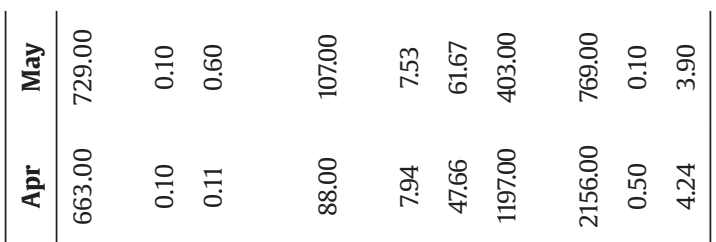

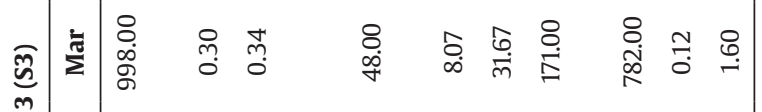

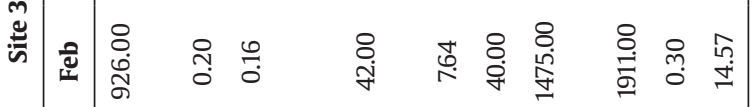

五

ปั

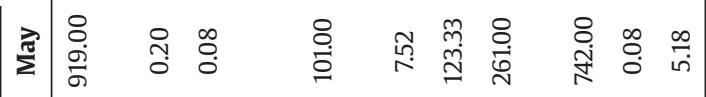

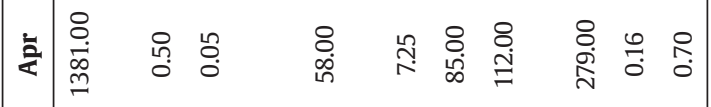

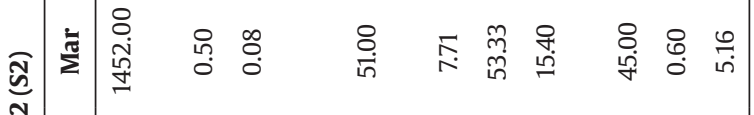

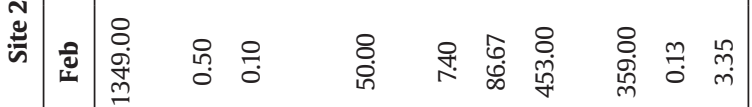

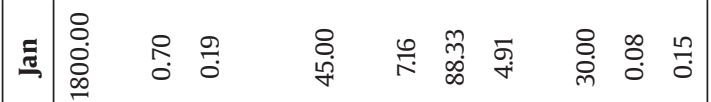

प

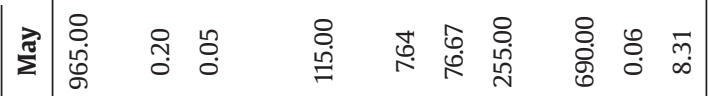

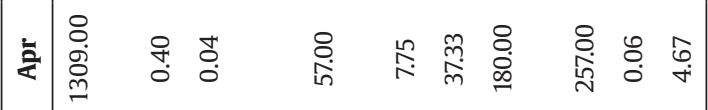

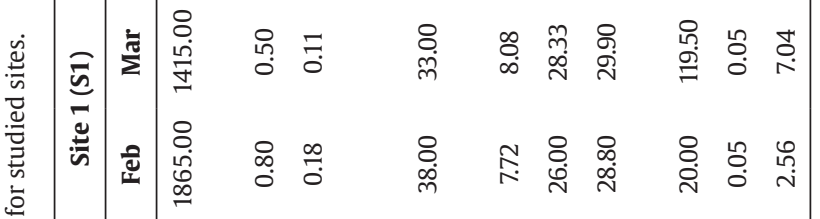

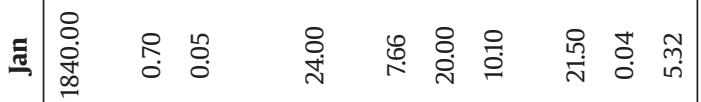

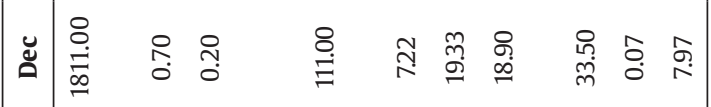

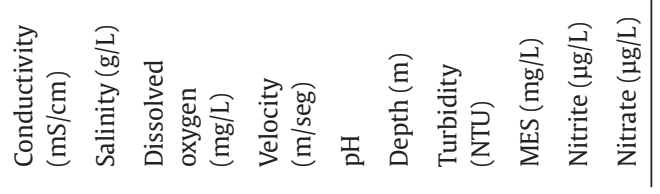

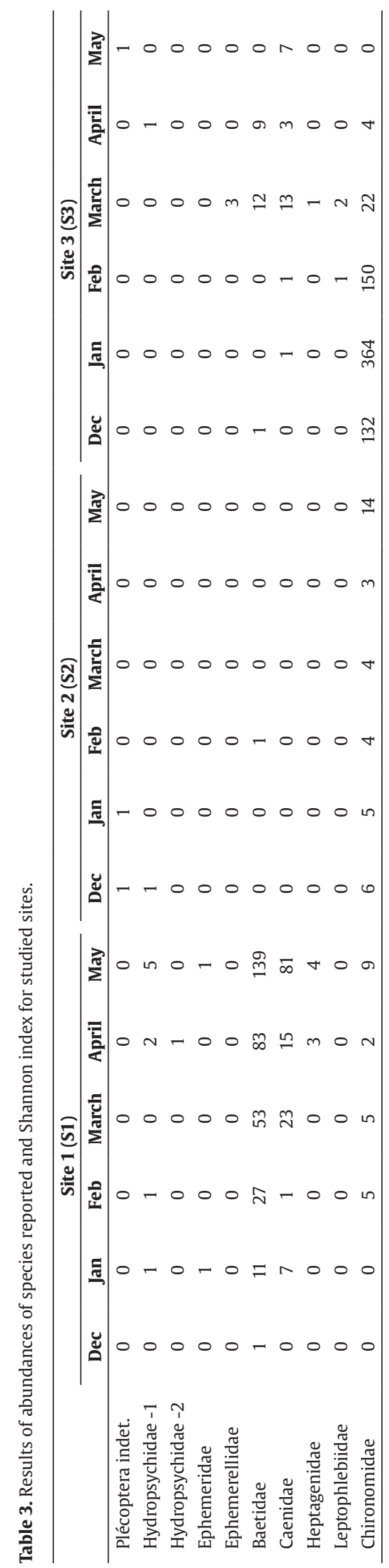




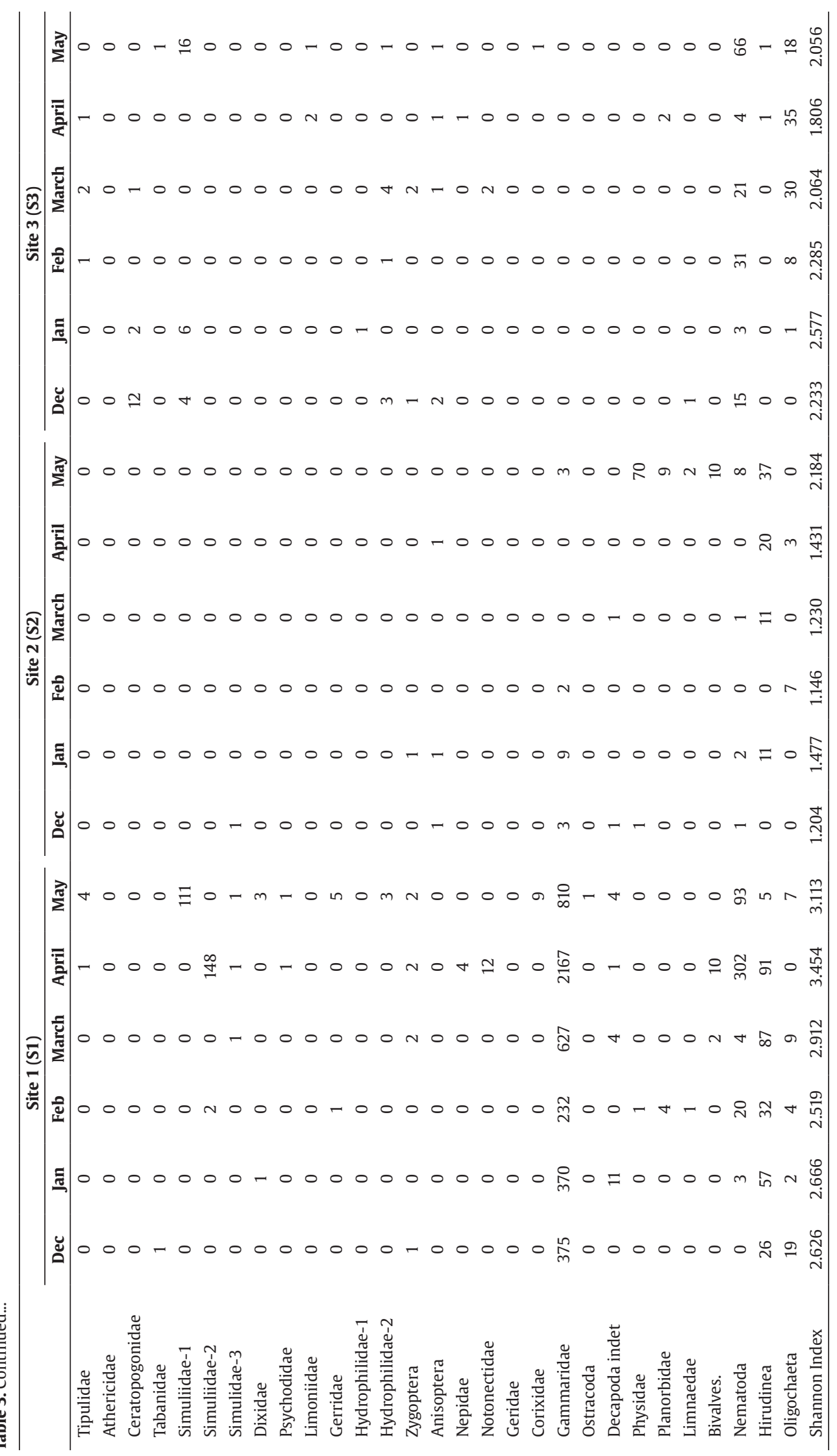




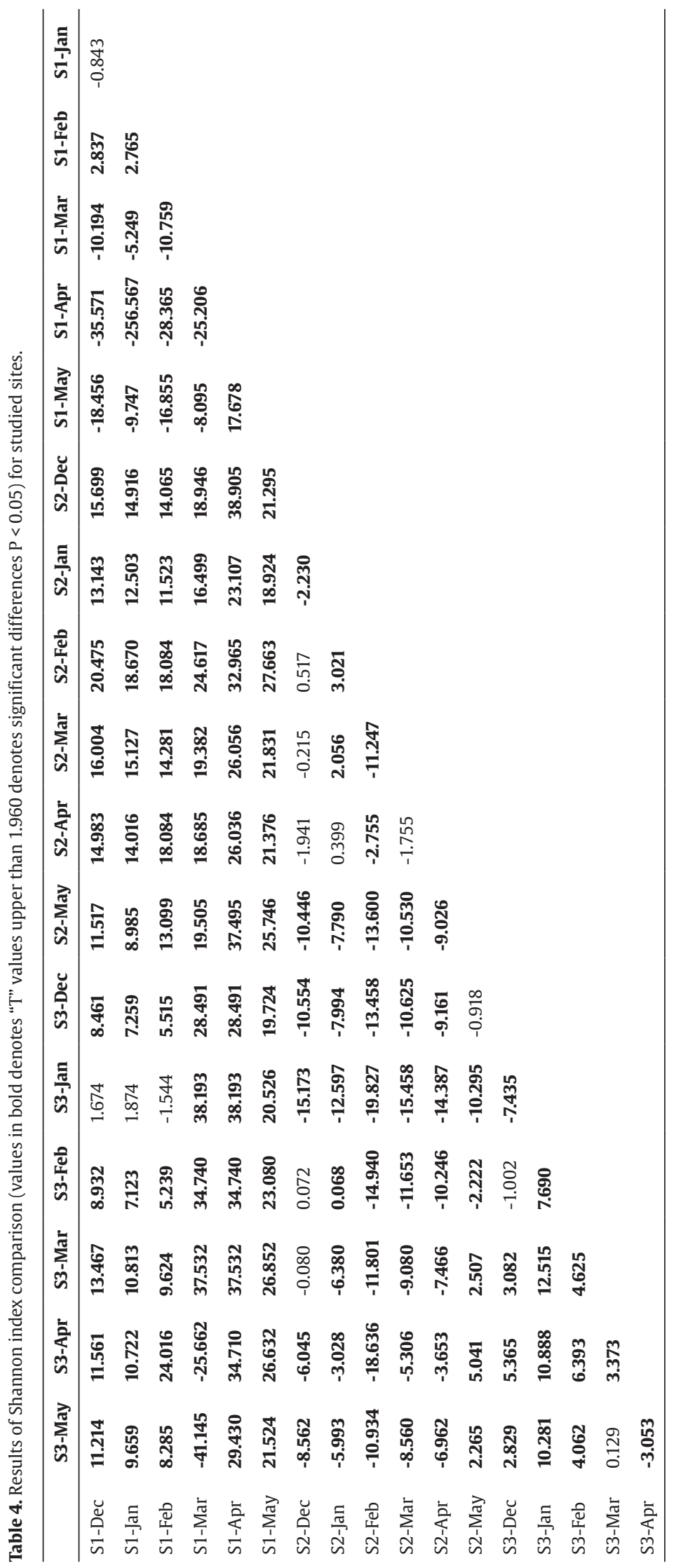


Table 5. Results of null model analysis for studied sites.

\begin{tabular}{cccccc}
\hline Site & Mean index & Observed index & $\begin{array}{c}\text { Standard effect } \\
\text { size }\end{array}$ & Variance & P \\
\hline Site 1 & 0.652 & 0.634 & -0.717 & $<0.001$ & 0.727 \\
Site 2 & 1.167 & 1.150 & -0.486 & 0.001 & 0.700 \\
Site 3 & 1.184 & 1.150 & -0.801 & 0.001 & 0.829 \\
\hline Month period & Mean index & Observed index & Standard effect & Variance & $\mathbf{P}$ \\
\hline December & 0.692 & 0.679 & -0.732 & $<0.001$ & 0.999 \\
January & 0.611 & 0.595 & -0.977 & $<0.001$ & 0.999 \\
February & 0.625 & 0.595 & -0.923 & 0.001 & 0.999 \\
March & 0.353 & 0.374 & 1.419 & $<0.002$ & 0.303 \\
April & 0.178 & 0.199 & 1.674 & $<0.001$ & 0.195 \\
May & 0.453 & 0.438 & -1.001 & $<0.001$ & 0.858 \\
\hline
\end{tabular}

(2021), who found associations between groups reported and environmental parameters for Chilean North Patagonian rivers. In this scenario, the macroinvertebrate assemblage fauna in the studied river is similar to observations for central and southern Chilean rivers (35-40우 S; Fierro et al., 2015; Figueroa et al., 2003, 2007, 2013; Vega et al., 2020; Barile et al., 2021), where it was found marked differences in community structure in function to river zone, where it is possible found that in high zones there are shredders (Ephemeroptera, Plecoptera) that requires water quality with high oxygen content and low dissolved organic matter contents and nutrient concentration (Moya et al., 2009; Oyanedel et al., 2008; Miserendino et al., 2018; De los Ríos-Escalante et al., 2020; Solis-Lufi et al., 2021). A different situation occurs in medium and low zones of the river where shredders decreased in abundances being replaced by mainly filterers due increase in nutrients and dissolved organic matter concentrations (Figueroa et al., 2003, 2007; Allan and Castillo, 2007; Hauer and Lamberti, 2007; Huttunen et al., 2017; Marcarelli et al., 2020; Figueroa and Ríos-Escalante, 2021).

The observed results are similar with other similar descriptions for Algerian rivers, where was found important differences in environmental parameters and community parameters in function of human intervention of surrounding basins (Reggam et al., 2015; Sellam et al., 2017, 2019; Baaloudj et al., 2020). Nevertheless, the results obtained in the present study that revealed the marked importance of amphipods would agree with results of Rouibi et al. (2021) who described the marked abundance of crustaceans in Bouhamdane river in Algeria. It is a similar situation in comparison to Algerian rivers in Boumerzoug (East of Algeria) where it was found marked absence of Plecoptera in spite of high-water quality (Bekhouche et al., 2017). In spite of these rivers are located in Mediterranean basin, the observed results are markedly opposite to results observed for Spain and other sites of Mediterranean climate such as California and central Chile (Figueroa et al., 2013), this gradient of benthic insects' community along
Chilean rivers (Figueroa et al., 2007; Figueroa and RíosEscalante, 2021).

These results revealed the existence of high conductivity level for sites 2 and 3 in comparison to site 1, in spite of relatively similar level of salinity, nitrite and nitrate levels, probably would indicate the presence of other anions and cations that were not included in the present study what would explain the high conductivity level of sites 2 and 3. On this basis, the role of chemical parameters specifically conductivity as regulator of community structure has been reported for Chilean Mediterranean rivers (Figueroa et al., 2007, 2013), that would be similar with other results for Algerian rivers (Bekhouche et al., 2017), these antecedents would be similar to the results of the present study.

In this context, the variation of macroinvertebrate communities along the course of the studied river would agree with classic concepts of river continuum (Allan and Castillo, 2007), that described the gradual replacement of fauna in function of water quality due human alteration, that was similar to descriptions for Cautin river in northern Chilean Patagonia (38오 S, Figueroa and RíosEscalante, 2021). Also, on the view point of differences in community structures in the course of river regulated by water quality, it involves also, the trophic relations, and in according to these relations the concept of functional groups is relevant, because the trophic resources vary along river course under natural conditions, that can enhance due human alterations, that in consequence affects the grazer or predator macroinvertebrate composition (Allan \& Castillo, 2007; Miserendino et al., 2018).

Other important topic, benthic taxonomic identification is very important for do a more robust and sensitive comparison between other similar fluvial ecosystems (Hauer and Lamberti, 2007; Moison et al., 2010), it is very important topic because the environmental sensitivity is variable for each species, that would generate differences in tolerance if we compared ecosystems of different hemispheres, because many benthic macroinvertebrate water quality index are standardized for determined regions, and perhaps can be marked differences if these 
Table 6. Results of RDA for abiotic and biotic parameters for studied sites.

\begin{tabular}{|c|c|c|c|c|c|}
\hline & Axis 1 & Axis 2 & & Axis 1 & Axis 2 \\
\hline Conductivity & PC1 & PC2 & Plecoptera & $-84,60$ & 12,41 \\
\hline Salinity & $-5143,48$ & $-796,38$ & Hydropsychidae & $-80,96$ & 12,36 \\
\hline Oxygen & 891,21 & $-452,92$ & Nymphe & $-83,72$ & 12,44 \\
\hline Velocity & 892,54 & $-452,37$ & Ephemeridae & $-84,13$ & 12,43 \\
\hline $\mathrm{pH}$ & 668,64 & $-367,53$ & Ephemerellidae & $-84,60$ & 12,29 \\
\hline Depth & 862,35 & $-446,37$ & Baetidae & 52,08 & 9,70 \\
\hline NTU & 698,32 & $-395,39$ & Caenidae & $-37,97$ & 9,72 \\
\hline MES & 27,84 & 1355,01 & Heptagenidae & $-80,65$ & 12,35 \\
\hline Nitrite & $-664,69$ & 2450,72 & Leptophlebiidae & $-84,60$ & 11,98 \\
\hline \multirow[t]{30}{*}{ Nitrate } & 892,87 & $-452,05$ & Chironomidae & $-80,30$ & $-403,84$ \\
\hline & 874,40 & $-442,72$ & Tipulidae & $-82,42$ & 11,93 \\
\hline & & & Athericidae & $-84,60$ & 12,44 \\
\hline & & & Ceratopogonidae & $-84,63$ & 6,84 \\
\hline & & & Tabanidae & $-84,45$ & 12,44 \\
\hline & & & Simuliidae & $-48,32$ & 4,89 \\
\hline & & & larve & 45,97 & 12,16 \\
\hline & & & Nymphe & $-83,14$ & 12,41 \\
\hline & & & Dixidae & $-83,47$ & 12,42 \\
\hline & & & Psychodidae & $-83,40$ & 12,43 \\
\hline & & & Limoniidae & $-84,60$ & 12,42 \\
\hline & & & Gerridae & $-82,87$ & 12,38 \\
\hline & & & Hydrophilidae & $-84,61$ & 11,56 \\
\hline & & & Non identified & $-83,63$ & 10,90 \\
\hline & & & Zygoptère & $-81,53$ & 11,98 \\
\hline & & & Anisoptère & $-84,60$ & 11,71 \\
\hline & & & Nepidae & $-81,08$ & 12,42 \\
\hline & & & notonectidae & $-74,03$ & 12,32 \\
\hline & & & Geridae & $-84,60$ & 12,44 \\
\hline & & & corixidae & $-81,66$ & 12,36 \\
\hline & & & Gammaridae & 2380,40 & $-0,42$ \\
\hline & & & Ostracode & $-84,28$ & 12,43 \\
\hline & & & crevette d'eau douce & $-79,77$ & 12,42 \\
\hline & & & Physidae & $-84,49$ & 10,61 \\
\hline & & & Planorbidae & $-84,23$ & 12,16 \\
\hline & & & Limnaedae & $-84,51$ & 12,06 \\
\hline & & & Bivalves & $-75,29$ & 12,16 \\
\hline & & & Nématodes & 215,26 & $-9,13$ \\
\hline & & & Hirudinae(Sangsue) & 34,54 & 10,71 \\
\hline & & & (Lombricidae) & $-76,51$ & 6,73 \\
\hline
\end{tabular}

are applied in other regions (Figueroa et al., 2003; 2007). Perhaps, an example can be the situation of Cautin river in northern Chilean Patagonia where the first studies proposed only the species that can be found in the river based in descriptions in one or two sites in the medium course in 1980 decades (Vega et al., 2020), whereas in 
studies done between 1999-2001, that involved fauna along the course found marked differences along benthic fauna, but it was not applied benthic macroinvertebrate water quality (Figueroa and Ríos-Escalante, 2021), due probably the absence of environmental tolerance of native species.

\section{Acknowledgements}

B.A. was funded by MESRS and the DGRSDT, projects FONDECYT INCIACIÓN N¹1160650 (ANID ex - CONICYTChile)(CE), and MECESUP UCT 0804 (PDE). The authors express their gratitude to M.I. and S.M.A for their valuable suggestions which improved the manuscript.

\section{References}

AÏT-MOULOUD, S., 1987 Essai de recherches sur la dérive des macroinvertébrès aquatiques dans l'oued Aïssi: faunistique, écologie et biogéographie. Argel: Université d'Alger, 118 p. Master thesis.

ALGERIA, MINISTÈRE DE L'ÉQUIPEMENT ET DE L'AMÉNAGEMENT DU TERRITOIRE, AGENCE DES BASSINS HYDROGRAPHIQUECONSTANTINOIS-SEYBOUSE-MELLEGUE, 1999. ConstantinoisSeybousse-Mellegue basin agency. Argel: Ministère de l'Équipement et de l'Aménagement du Territoire.

ALLAN, J.D. and CASTILLO, M.M., 2007. Stream ecology, structure and function of running waters. 2nd ed. Cham: Springer, $436 \mathrm{p}$.

ARAB, A. and ZEBDI, A., 1983. Contribution à l'évaluation de la qualité de l'eau des oueds de la Mitidja. Alger: USTHB, 106 p.

ARCHAIMBAULT, V. and DUMONT, B., 2010. L'indice biologique global normalisé (IBGN): principes et évolution dans le cadre de la directive-cadre européenne sur l'eau. Sciences Eaux $\mathcal{E}$ Territoires, no. 1, pp. 36-39.

ASSOCIATION FRANÇAISE DE NORMALIZATION - AFNOR, 2010. Qualité écologique des milieux aquatiques. Qualité de l'eau. Traitement au laboratoire d'échantillons contenant des macroinvertébrés des cours d'eau Prénorme expérimentale XP T90-333. Paris: Association Française de Normalization.

BAALOUDJ, A., SAMIA, O., MOHAMED, B., HADIA, R., HUSSEIN, A. A., CHAYMA, H. and HAROUNA, N. D. D., 2020. Use of macro invertebrates to assess the quality of Seybouse River (NorthEast of Algeria). Ukrainian Journal of Ecology, vol. 10, no. 4, pp. 60-66. http://dx.doi.org/10.15421/2020_168.

BARBOUR, M.T., GERRITSEN, J., GRIFFITH, G.E., FRYDENBORG, R., MCCARRON, E., WHITE, J.S. and BASTIAN, M.L., 1996. A framework for biological criteria for Florida streams using benthic macroinvertebrates. Journal of the North American Benthological Society, vol. 15, no. 2, pp. 185-211. http://dx.doi. org/10.2307/1467948.

BARBOUR, M.T., GERRITSON, J., SNYDER, B.D. and STRIBLING, J.B., 1999. Rapid bioassessment protocols for use in wadeable streams and rivers: periphyton, benthic macroinvertebrates and fish. 2nd ed. Washington D.C.: Environmental Protection Agency.

BARILE, J., VEGA, R. and DE LOS RÍOS-ESCALANTE, P., 2021. First report the role of benthic macroinvertebrates as preys for native fish in Toltén river ( $38^{\circ} \mathrm{S}$, Araucania region Chile). Brazilian journal of biology = Revista Brasileira de Biologia, vol. 81, no. 3, pp. 845-853. http://dx.doi.org/10.1590/1519-6984.232661. PMid:32965340.

BEKHOUCHE, N., MARNICHE, F. and OULDJAOUI, A., 2017. Contribution to the study of the biodiversity of benthic invertebrates and the biological quality of some rivers in the watershed Boumerzoug (East of Algeria).Journal of Fundamental and Applied Sciences, vol. 9, no. 1, pp. 234-260. http://dx.doi. org/10.4314/jfas.v9i1.16.

BELHANACHI, A. 2003. Etude hydrologique et hydro chimique dans les bassins versants du Nord-Est Algérien “Bassin de la Seybouse, Kébir Est, Kébir Ouest et Saf Saf”. Annaba: Université d'Annaba, 177 p. Masters thesis.

BLAYAC, J., 1912. Esquisse Géologique du Bassin de la Seybouse et de quelques régions voisines. Cartes et coupes Géologiques. Alger: Adolphe Jourdan, $491 \mathrm{p}$.

BUTCHER, J.N., ARBISI, P.A., ATLIS, M.M. and MCNULTY, J.L., 2003. The construct validity of the Lees-Haley Fake-Bad Scale (FBS): does this scale measure somatic malingering and feigned emotional distress? Archives of Clinical Neuropsychology, vol. 18, no. 5, pp. 473-485. http://dx.doi.org/10.1016/j.acn.2008.10.001. PMid:14591444.

CARVAJAL-QUINTERO, J.D., ESCOBAR, F., ALVARADO, F., VILLANAVARRO, F.A., JARAMILLO-VILLA, Ú. and MALDONADOOCAMPO, J.A., 2015. Variation in freshwater fish assemblages along a regional elevation gradient in the northern Andes, Colombia. Ecology and Evolution, vol. 5, no. 13, pp. 2608-2620. http://dx.doi.org/10.1002/ece3.1539. PMid:26257874.

DE LOS RÍOS-ESCALANTE, P., ESSE, C., SANTANDER-MASSA, R., SAAVEDRA, P. and ENCINA-MONTOYA, F., 2020. Benthic macroinvertebrate communities in sites with native forest presence and absence in north Patagonia. Iheringia. Série Zoologia, vol. 110, pp. e2020014. http://dx.doi.org/10.1590/1678$4766 \mathrm{e} 2020014$.

DJABRI L., FERRAH Y., BOUHSINA S., CAZIER F., HANI A., DJABRI Y., BOSCH A.P., and SAME H., 2012. Etats de la qualité des eaux en Algérie: cas des cours d'eau en région méditerranéenne (Kebir est, Seybouse et Medjerda), (extrême est algérien). In: XII Journées Nationales Génie Côtier - Génie Civil Cherbourg, 12-14 Juin 2012, Cherbourg. Cherbourg: Centre Français du Littoral.

DJERIDANE, Y. and SALHI, S., 1983. Contribution à l'étude de la qualité de l'eau des oueds de la qualité de la Mitidja par application de l'écologie des macro-invertébrés. Alger: USTHB, 128 p.

FIERRO, P., BERTRAN, C., MERCADO, M., PENA CORTES, F., TAPIA, J., HAUENSTEIN, E., CAPUTO, L. and VARGAS CHACOFF, L., 2015. Landscape composition as determinant of diversity and functional feeding groups of aquatic macroinvertebrates in southern rivers of the Araucania, Chile. Latin American Journal of Aquatic Research, vol. 43, no. 1, pp. 186-200. http://dx.doi. org/10.3856/vol43-issue1-fulltext-16.

FIGUEROA, D. and DE LOS RÍOS-ESCALANTE, P., 2021. Macrozoobenthos in an altitudinal gradient in North Patagonian Cautín River (Araucanía Region, Chile). Brazilian Journal of Biology = Revista Brasileira de Biologia, vol. 82, pp. e240484. http://dx.doi.org/10.1590/1519-6984.240484. PMid:34105648.

FIGUEROA, R., BONADA, N., GUEVARA, M., PEDREROS, P., CORREAARANEDA, F., DÍAZ, M.E. and RUIZ, V.H., 2013. Freshwater biodiversity and conservation in Mediterranean climate streams of Chile. Hydrobiologia, vol. 719, no. 1, pp. 269-289. http:// dx.doi.org/10.1007/s10750-013-1685-4.

FIGUEROA, R., PALMA, A., RUIZ, V. and NIELL, X., 2007. Análisis comparativo de índices bióticos utilizados en la evaluación de la calidad de aguas en un río mediterráneo de Chile, río Chillán, VIII región. Revista Chilena de Historia Natural, vol. 80, no. 2, pp. 225-242. http://dx.doi.org/10.4067/S0716078X2007000200008.

FIGUEROA, R., VALDOVINOS, C., ARAYA, E. and PARRA, O., 2003. Macroinvertebrados bentónicos como indicadores de calidad de agua de ríos del sur de Chile. Revista Chilena de Historia 
Natural, vol. 76, no. 2, pp. 275-285. http://dx.doi.org/10.4067/ S0716-078X2003000200012.

GAGNEUR, J. and ALIANE, N., 1991. Contribution à la connaissance des Plécoptères d'Algérie. In: J. Alba-Tercedor and A. SánchezOrtega, eds. Overview and strategies of Ephemeroptera and Plecoptera. Gainesville: Sandhill Crane Press, pp. 311-324.

GAGNEUR, J., 1987. Contribution à la connaissance des Ephéméroptères d'Algérie. Bulletin de la Société d'Histoire Naturelle de Toulouse, vol. 124, pp. 213-223.

GOTELLI, N.J. and ELLISON, A.M., 2013. [viewed 19 February 2020]. EcoSimR: null models for ecology. Version 1.00 [online]. Available from: http://www.uvm.edu/ ngotelli/EcoSim/EcoSim.html

GOTELLI, N.J., 2000. Null models of species co-ocurrence patterns. Ecology, vol. 81, no. 9, pp. 2606-2621. http://dx.doi. org/10.1890/0012-9658(2000)081[2606:NMAOSC]2.0.CO;2.

HARRELL, F.E., 2016. [viewed 1 December 2019]. Package "Hmisc" [online]. Available from: https://cran.r-project.org/web/ packages/Hmisc/Hmisc.pdf.

HAUER, F.R. and LAMBERTI, G.A., 2007. Methods in stream ecology. Amsterdam: Academic Press, 865 p.

HELLAWELL, J.M., 1986. Biological Indicators of Freshwater Pollution and Environmental Management. In K. Melanby, eds. Pollution monitoring series, 546 p. http://dx.doi.org/10.1007/978-94009-4315-5.

HUTTUNEN, K.-L., MYKRÄ, H., OKSANEN, J., ASTORGA, A., PAAVOLA, R. and MUOTKA, T., 2017. Habitat connectivity and in-stream vegetation contron temporal variability of benthic invertebrate communities. Scientific Reports, vol. 7, no. 1, pp. 1448. http:// dx.doi.org/10.1038/s41598-017-00550-9. PMid:28469187.

KARR, J.R. and DUDLEY, D.R., 1981. Ecological perspectives on water quality goals. Environmental Management, vol. 5, no. 1, pp. 55-68. http://dx.doi.org/10.1007/BF01866609.

KHELIFA, R., 2019. Sensitivity of biodiversity indices to life history stage, habitat type and landscape in Odonata community. Biological Conservation, vol. 237, pp. 63-69. http://dx.doi. org/10.1016/j.biocon.2019.06.010.

KHELIFA, R., MAHDJOUB, H., BAALOUDJ, A., CANNINGS, R.A. and SAMWAYS, M.J., 2021a. Remarkable population resilience in a North African endemic damselfly in the face of rapid agricultural transformation. Insects, vol. 12, no. 4, pp. 353. http://dx.doi. org/10.3390/insects12040353. PMid:33920977.

KHELIFA, R., MAHDJOUB, H., BAALOUDJ, A., CANNINGS, R.A. and SAMWAYS, M.J., 2021b. Effects of both climate change and human water demand on a highly threatened damselfly. Scientific Reports, vol. 11, no. 1, pp. 7725. http://dx.doi.org/10.1038/ s41598-021-86383-z. PMid:33833264.

KHELIFA, R., ZEBSA, R., AMARI, H., MELLAL, M.K., MAHDJOUB, H. and KAHALERRAS, A., 2016. A hotspot for threatened Mediterranean odonates in the Seybouse River (Northeast Algeria): are IUCN population sizes drastically underestimated? International Journal of Odonatology, vol. 19, no. 1-2, pp. 1-11. http://dx.doi. org/10.1080/13887890.2015.1133331.

LERAUT, P., 2007. Ébauche d'une liste des pyrales de France [Lepidoptera, Pyraloidea]. [Preliminary list of pyralids moths from France (Lepidoptera, Pyraloidea).]. Revue Française d'Entomologie, vol. 29, no. 4, pp. 149-166.

LOUNACI, A. 1987. Recherches hydrobiologiques sur les peuplements d'invertébrés benthiques du bassin de l'oued Aïssi (Grande Kabylie). Alger: Université USTHB d'Alger, 145 p. Masters thesis.

LOUNACI, A. 2005. Recherche sur la faunistique, l'écologie et la biogéographie des macroinvertébrés des cours d'eau de Kabylie
(Tizi-Ouzou, Algérie). Tizi-Ouzou: Université Mouloud Mammeri de Tizi-Ouzou, 208 p. Masters thesis.

LOUNACI, A. and VINÇON, G., 2005. Les Plécoptères de la Kabylie du Djurdjura (Algérie) et biogéographie des espèces d'Afrique du Nord (Plecoptera). Ephemera, vol. 6, no. 2, pp. 109-124.

LOUNACI, A., BROSSE, S., THOMAS, A. and LEK, S., 2000. Abundance, diversity and community structure of macroinvertebrates in an Algerian stream: the Sébaou stream. Annales de Limnologie, vol. 36, no. 2, pp. 123-133. http://dx.doi.org/10.1051/limn/2000008.

MARCARELLI, A.M., BAXTER, C.V., BENJAMIN, J.R., MIYAKE, Y., MURAKAMI, M., FAUSCH, K.D. and NAKANO, S., 2020. Magnitude and direction of stream-forest community interactions change with timescale. Ecology, vol. 101, no. 8, pp. e03064. http:// dx.doi.org/10.1002/ecy.3064. PMid:32274791.

MEZIANE, K., KERFOUF, A. and BAALOUDJ, A., 2020. Checklist of gastropod molluscs in west coast of Algeria. International Journal of Aquatic Biology, vol. 8, pp. 224-227.

MISERENDINO, M., BRAND, C., EPELE, L.B., DI PRINZIO, C.Y., OMAD, G.H., ARCHANGELSKY, M., MARTINEZ, O. and KUTSCHKER, A.M., 2018. Biotic diversity of benthic macroinvertebrates at contrasting glacier-fed systems in Patagonia Mountains: the role of environmental heterogeneity facing global warming. The Science of the Total Environment, vol. 622-623, pp. 152-163. http:// dx.doi.org/10.1016/j.scitotenv.2017.11.320. PMid:29212052.

MOISON, M., ROUX, F., QUADRADO, M., DUVAL, R., EKOVICH, M., LÊ, D.H., VERZAUX, M. and BUDAR, F., 2010. Cytoplasmic phylogeny and evidence of cyto-nuclear co-adaptation in Arabidopsis thaliana. The Plant Journal, vol. 63, no. 5, pp. 728-738. http:// dx.doi.org/10.1111/j.1365-313X.2010.04275.x. PMid:20553420.

MOUBAYED-BREIL, J., LOUNACI, A. and LOUNACI-DAOUDI, D., 2007. Non-biting midges from Algeria, North Africa (Diptera, Chironomidae). Ephemera, vol. 8, no. 2, pp. 93-99.

MOYA, C., VALDOVINOS, C., MORAGA, A., ROMERO, F., DEBELS, P. and OYANEDEL, A., 2009. Patrones de distribución espacial de ensambles de macroinvertebrados bentónicos de un sistema fluvial Andino Patagónico. Revista Chilena de Historia Natural, vol. 82, no. 3, pp. 425-442. http://dx.doi.org/10.4067/S0716078X2009000300009.

NORRIS, R.H. and HAWKINS, C.P., 2000. Monitoring river health. Hydrobiologia, vol. 435, no. 1/3, pp. 5-17. http://dx.doi. org/10.1023/A:1004176507184.

OKSANEN, J., BLANCHET, F.G., FRIENDLY, M., KINDT, R., LEGENDRE, P., MCGLINN, D., O'HARA, R.B., SIMPSON, G.L., SOLYMOS, P., STEVENS, M.H.H., SZOECS, E. and WAGNER, H., 2019. [viewed 1 October 2019]. Package “Vegan" [online]. R Project. Available from: https://cran.r-project.org/web/packages/vegan/vegan.pdf.

OYANEDEL, A., VALDOVINOS, C., AZOCAR, M., MOYA, C., MANCILLA, G., PEDREROS, P. and FIGUEROA, R., 2008. Patrones de distribución espacial de los macroinvertebrados bentónicos de la cuenca del río Aysen (Patagonia Chilena). Gayana, vol. 72, no. 2, pp. 241-257. http://dx.doi.org/10.4067/S071765382008000200011.

R DEVELOPMENT CORE TEAM, 2009. R: A language and environment for statistical computing. Vienna: R Foundation for Statistical Computing.

REGGAM, A., BOUCHELAGHEM, E.H. and HOUHAMDI, M., 2015. Qualité physico-chimique des eaux de l'Oued Seybouse (NordEst de l'Algérie): caractérisation et analyse en composantes principales. Journal of Materials and Environmental Science, vol. 6, no. 5, pp. 1417-1425.

ROUIBI, A., BAALOUDJ, A., CHAHROUR, F., KERFOUF, A., RIZI, H., BERDJA, R., BELKHIRIA, W., CHAIB, S. and GHARBI, M., 2021. Characterization and diversity of macroinvertebrates 
of the Bouhamdane stream (Northeast of Algeria). Zoology and Ecology, vol. 31, no. 1, pp. 45-52. http://dx.doi. org/10.35513/21658005.2021.1.8.

SELLAM, N., VIÑOLAS, A., ZOUGGAGHE, F. and MOULAI, R., 2019. Assesment of the physico-chemical and biological quality of surface waters in arid and semi-arid regions of Algeria. Bulletin de la Société Zoologique de France, vol. 144, no. 4, pp. 157-178.

SELLAM, N., ZOUGGACHE, F., PINEL-ALLOUL, B., MIMOUNI, A. and MOULAI, R., 2017. Taxa richness and community structure of macroinvertebrates in rivers of different bioclimatic regions of Algeria. Journal of Materials and Environmental Sciences, vol. 8, no. 5, pp. 1574-1588.

SOLIS-LUFI, K., SUAZO, M.J., AVILA-SALEM, M.E., MALDONADOMURUA, C., APONTE, H., FARIAS, J. and RÍOS-ESCALANTE, P., 2021. Community structure of benthic invertebrates in the Allipén River basin, North Patagonia, Araucania region ( $38^{\circ} \mathrm{S}$, Chile). Brazilian Journal of Biology $=$ Revista Brasileira de Biologia, vol. 82, pp. e232805. http://dx.doi.org/10.1590/1519-6984.232805. PMid:33787712.

TACHET, H., RICHOUX, P., BOURNAUD, M. and USSEGLIO-POLATERA, P., 2010. Invertébrés d'eau douce : systématique, biologie, écologie. Paris: CNRS Editions, 588 p.

TIHO, S. and JOSENS, G., 2007. Co-occurrence of earthworms in urban surroundings: A null model analysis of community structure. European Journal of Soil Biology, vol. 43, no. 2, pp. 84-90. http://dx.doi.org/10.1016/j.ejsobi.2006.10.004.
TONDOH, J.E., 2006. Seasonal changes in earthworm diversity and community structure in Central Côte d'Ivoire. European Journal of Soil Biology, vol. 42, pp. S334-S340. http://dx.doi. org/10.1016/j.ejsobi.2006.09.003.

VEGA, R., DE LOS RÍOS-ESCALANTE, P., ENCINA, F., NORAMBUENA, J.A., BARILE, J. and MARDONES, A., 2020. First reports of inventory and role of macroinvertebrate and fish in Cautín River $\left(38^{\circ} \mathrm{S}\right.$, Araucania region, Chile). Brazilian Journal of Biology = Revista Brasileira de Biologia, vol. 80, no. 1, pp. 215-228. http://dx.doi. org/10.1590/1519-6984.203511. PMid:31066767.

WARWICK, R.M. and CLARKE, K.R., 1993. Comparing the severity of disturbance: a meta-analysis of marine macrobenthic community data. Marine Ecology Progress Series, vol. 92, no. 3, pp. 221-231. http://dx.doi.org/10.3354/meps092221.

ZAR, J.H., 1999. Biostatistical analysis. New Jersey: Prentice Hall, Inc., $661 \mathrm{p}$.

ZOUGGAGHE, F. and MOALI, A., 2009. Variabilité structurelle des peuplements de macro-invertébrés benthiques dans le bassin versant de la Soummam (Algérie, Afrique du Nord). Revue Écologie - La Terre et la Vie, vol. 64, no. 4, pp. 305-321.

ZOUGGAGHE, F., 2003. Etude des communautés d'invertébrés dans l'oued Soummam. Béjaïa: Université Abderrahmane Mira de Béjaia, 74 p. Masters thesis.

ZOUGGAGHE, F., 2020. Structure et distribution des macro-invertébrés aquatiques e la kabylie de la Soummam (nord de l'Algérie). Bulletin de la Société Zoologique de France, vol. 145, no. 3, pp. 295-310. 